\title{
Article \\ Differences of Pore Features in Marine Shales between Lower Cambrian and Lower Silurian Formations of Upper Yangtze Area, South China
}

\author{
Minghui Li ${ }^{1}$, Mingliang Li ${ }^{2}$, Haiping Huang ${ }^{1}$, Lei Gong ${ }^{3, * \mathbb{D}}$ and Debao Zheng ${ }^{4}$ \\ 1 School of Energy Resource, China University of Geosciences (Beijing), Beijing 100083, China; \\ limixi@cugb.edu.cn (M.L.); huah@ucalgary.ca (H.H.) \\ 2 Production Operation Department, Qinghe Oil Production Plant of Sinopec Shengli Oilfield Co., Ltd., \\ Weifang 262714, China; ling2675@126.com \\ 3 Bohai-Rim Energy Research Institute, Northeast Petroleum University, Qinhuangdao 066004, China \\ 4 Downhole Operations Company, Daqing Oilfield, CNPC, Daqing 163453, China; Zheng1010@163.com \\ * Correspondence: kcgonglei@foxmail.com
}

Citation: Li, M.; Li, M.; Huang, H.; Gong, L.; Zheng, D. Differences of Pore Features in Marine Shales between Lower Cambrian and Lower Silurian Formations of Upper Yangtze Area, South China. Energies 2022, 15, 820. https://doi.org/ $10.3390 /$ en15030820

Academic Editor: Reza Rezaee

Received: 1 October 2021

Accepted: 7 December 2021

Published: 24 January 2022

Publisher's Note: MDPI stays neutral with regard to jurisdictional claims in published maps and institutional affiliations.

Copyright: (c) 2022 by the authors Licensee MDPI, Basel, Switzerland. This article is an open access article distributed under the terms and conditions of the Creative Commons Attribution (CC BY) license (https:// creativecommons.org/licenses/by/ $4.0 /)$.

\begin{abstract}
Lower Cambrian shale and lower Silurian shale are both typical of oil-prone kerogen and siliceous composition, but different in thermal maturities. Porosity differences were determined in marine shales between the two shales. Measurements were utilized including organic geochemistry, $\mathrm{XRD}$, scanning electron microscopy (SEM) and $\mathrm{N}_{2}$ gas adsorption. Pore volume (PV) of lower Silurian shale was approximately 1.5 times higher than that of lower Cambrian shale, and pore surface area (PSA) of lower Silurian shale was almost 2.5 times higher than that of lower Cambrian shale. Lower Cambrian shale and lower Silurian shale possess similar materials, but distinctive thermal degrees. Evolution mechanisms of different types of pores, especially organic matter (OM)-hosted pores, may trigger this different pore features. Pores of rigid framework are the residue of primary interparticle pores during the burial history. Pores associated with clay flakes can be preserved well adjacent to rigid grains or secondary minerals acting as rigid frameworks or grain supporters. Dissolved pores in both lower Cambrian shale and lower Silurian shale barely contribute to the total porosity and mean little to the permeability. Both excessive OM content and over thermal maturity are detrimental to development of OM-hosted pores. Rigid particles, clay flakes, and OM commonly co-exist within shale matrix. Rigid grains act as supporters, clay flakes confine ample space, and OM first migrates into and provides secondary OM-hosted pores. In this condition, pores can be preserved owing to associating matrix with good mechanic and chemical stability. The significant differences of structural settings result into various hydrocarbon explosion efficiency and different pressure circumstance, which consequently leads to the different pore features between the two shales. For lower Cambrian shale, overpressure circumstance diminish if hydrocarbon expels outside of the shale system, and OM-hosted pores destroy through compaction. Sustaining overpressure and abundant residue hydrocarbon (migrated $\mathrm{OM}$ ) make positive contributions to the pore properties, in terms of numbers, diameters and connectivity of the lower Silurian shale samples.
\end{abstract}

Keywords: marine shale; lower Cambrian; lower Silurian; pore types; pore properties; porosity development mechanism

\section{Introduction}

Globally, the recoverable reserve $\left(3922 \times 10^{12} \mathrm{~m}^{3}\right)$ of unconventional natural gas is approximately 8.3 times greater than that of conventional type $\left(470.5 \times 10^{12} \mathrm{~m}^{3}\right)$ [1]. As a typical unconventional natural gas, shale gas is generally trapped within shale formation as free and adsorbed states [2,3]. As a combination of source and reservoir, gas-bearing shale control gas features in terms of occurrence phase, content and percolation [4-8]. 
The physical properties of gas-bearing shale are generally controlled by organic matter abundance, kerogen type, thermal evolution, hydrocarbon generation and expulsion conditions [9]. Characteristics of shale reservoir, especially pore properties has been studied by using mainly three types of experimental techniques: microscopic observation (e.g., scanning electron microscopy, transmission electron microscopy) [10-12], radiation detection (e.g., small or ultrasmall angle neutron scattering, nuclear magnetic resonance) $[13,14]$, and fluid invasion (e.g., gas adsorption, mercury intrusion, helium pycnometry) $[5,11,15,16]$.

OM-hosted pores gain more attention than primary interparticle pores $[8,9,17]$. Reaching to a certain thermal degree, OM can produce hydrocarbons accompanied by the development of OM-hosted pores [2,3]. With further burial and compaction, OM tend to be carbonized and pores associated with OM are compacted to collapse [18]. In the whole process of pore evolution, OM-hosted pore shows a unimodal trend, which increases first and then decreases with the peak at 3.5\% Ro [18].

In China, marine shales are characterized by wide distribution, remarkable thickness (e.g., up to $80 \mathrm{~m}$ in Sichuan Basin), OM abundance, oil-prone kerogen type and high thermal maturity $[2,3,14]$. Marine shales mainly distribute in the upper Yangtze region with an estimated recoverable resources of $8.8 \times 10^{12} \mathrm{~m}^{3}$ that account for $69 \%$ of shale gas $\left(12.85 \times 10^{12} \mathrm{~m}^{3}\right)$. Burial depths of marine shales range from 1000 to $6000 \mathrm{~m}$ with 30 100 m thickness of the single layer, which are mainly located in the lower Cambrian and lower Silurian Formations [19-21]. At present, several shale gas plays associated with marine shales are exploited in south China, such as Fuling, Changning-Weiyuan, Zhaotong, Fushun-Yongchuan, which all are located in lower Silurian Formation (Longmaxi Formation) [22]. However, the drilling results are uncommercial and unsatisfied in lower Cambrian Formation (Niutitang Formation), which is equally rich in OM of marine origin [22].

Due to the diversity of the original sedimentary materials and their evolution histories, properties of the two reservoirs, in terms of pore types, diameter, distribution, pore volume and surface area are different undoubtedly [23-25]. In order to guide the exploration and exploitation of shale gas reservoirs, researches on characteristics of reserving space, with direct controlling function on quantity and quality of shale gas, are imperative and enforced $[2,3]$.

Lower Cambrian shale and lower Silurian shale are both typical of oil-prone kerogen and siliceous composition, but different in thermal maturities. Comparative analysis between two distinctive layers with different capacity of gas content is feasible and inspectable. Measurements were utilized including OM abundance, thermal degree, XRD, scanning electron microscopy and gas adsorption. Parameters were obtained in terms of TOC, \% Ro, kerogen components, mineral composition, pore volume and pore surface area. Differences of pore features between lower Cambrian and lower Silurian shales and the main constraint were analyzed and discussed.

\section{Geological Setting}

The tectonic evolution of upper Yangtze area is complicated and has undergone many tectonic movements such as Tongwan, Caledonian, Hercynian, Indosinian and Himalayan [26,27] (Figure 1a). Horizontally, the upper Yangtze region has more superior conditions for shale gas accumulation than the margin of the basin, from the perspective of thermal evolution and burial history.

The sea level rose due to the ice melt in the period of Sinian [27], and during the sedimentary period of the lower Cambrian shale, the largest scale transgression of the Early Paleozoic occurred in Sichuan Basin with deep and stable water environment. The bottom of the water was an oxygen-deficient reducing environment with prosperous plants during Cambrian, which provided sufficient organic matter for the development of source rocks [21]. Lower Cambrian shale was mainly composed of deep-water continental shelf sediments during the high tide period of the transgression. Subsequently, the water gradually became shallower, resulting in the sea level decline. Consequently, the mud content decreased and the sand content generally increased. Therefore, the color of the sediment 
was gradually lightened, and the lithology gradually transitions to gray-yellow, gray-green mudstone with silt streaks, silty mudstone, and calcareous shale. Lower Cambrian shale is generally black shale with a stable layer with thickness reaching 70-90 m. TOC values are generally around $2.0 \%$ and $\%$ Ro is generally greater than $3.0 \%[22,23]$.
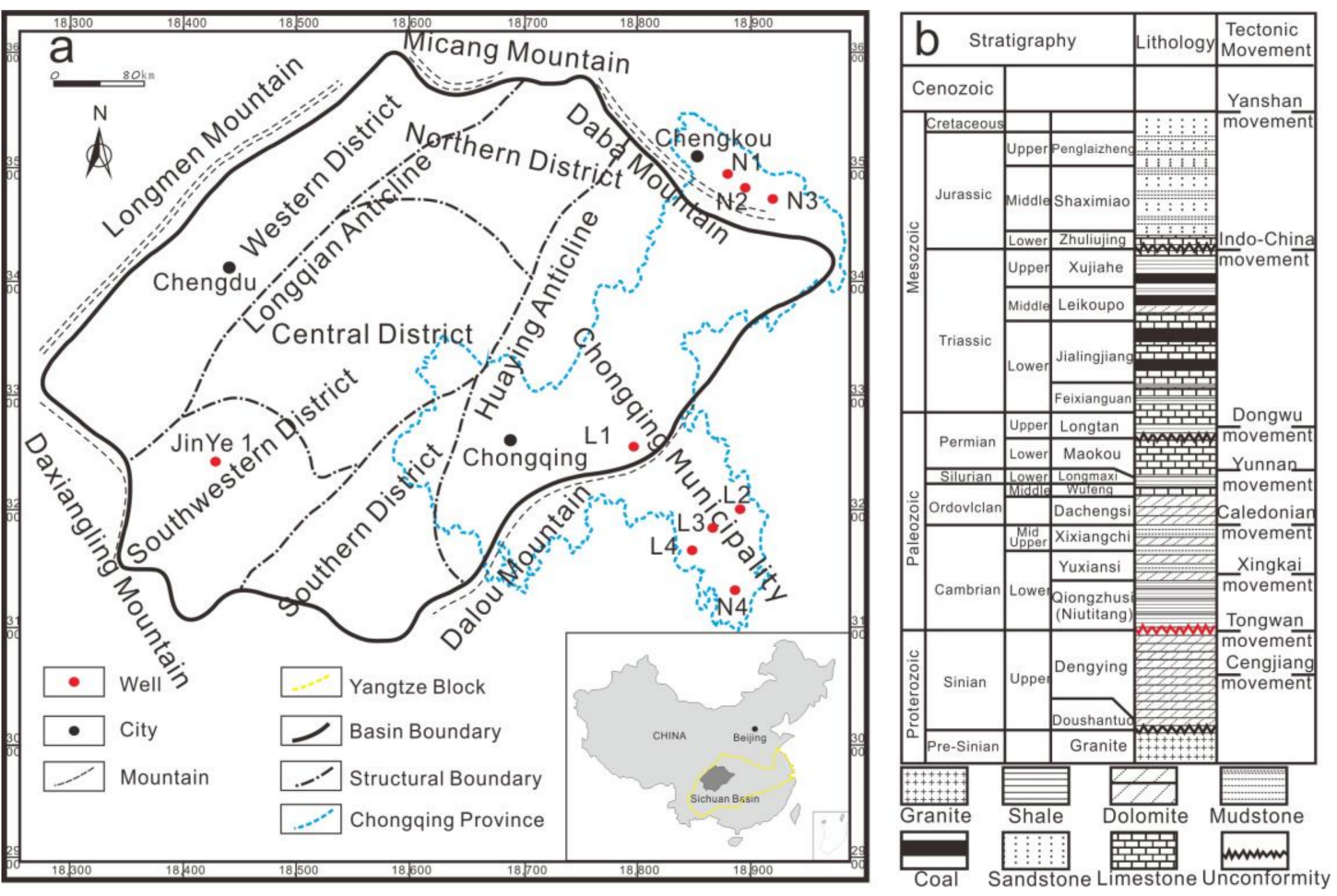

Figure 1. The location and stratigraphic column of the study area. (a) Geologic map of the study area in South China; well locations of lower Cambrian shale (N1, N2, N3, N4) and lower Silurian shale (L1, L2, L3, L4) are marked by the red points and (b) stratigraphic sequences in the Sichuan Basin.

From the end of the glacial period of Hernanite to the onset of deposition time of the lower Silurian shale, due to the melting of a wide range of glaciers, the sea level rose rapidly with deepening water body and hydrostatic conditions, providing good conditions for the development of source rock. In the early stage of lower Silurian shale, a set of black-gray, gray-black graptolite shale, mudstone and silty mudstone were deposited. The following sea level caused to decline and the supply of terrigenous materials increased [21]. Reducing environment destroyed resulting in a decrease in the organic matter of the sedimentary layer. Lower Silurian shale, with a maximum thickness of more than $100 \mathrm{~m}$, is composed of black, gray black, dark siliceous shale with shallow burial depth, generally at 1000 3500 m. TOC values of this lower Silurian shale mainly distributed in the range of $0.5-2.0 \%$, and the value of $\%$ Ro is generally greater within $2.0-3.0 \%$ [24].

In a whole, the two sets of shales, lower Cambrian and lower Silurian shales, generally have a denudation thickness of 1000-4000 m, but only lower Cambrian shale has experienced the Tongwan orogeny. An unconformity formed between the bottom of lower Cambrian shale and the top of Dengying formation as layers uplift and erosion [28,29] (Figure 1b).

\section{Experimental Procedures and Samples}

\subsection{Total Organic Carbon (TOC) and \% Ro Measurements}

Total organic carbon content was measured with the Leco CS230 carbon/sulfur analyzer. First, the samples will be broken and samples smaller than 80 mesh will be screened out. Then, the carbonates in the samples were removed using hydrochloric acid, and then the samples were washed with distilled water and the samples were pyrolyzed at $540{ }^{\circ} \mathrm{C}$ 
to finally measure the TOC. For lacking of higher land plants, rocks before the Devonian contain have no vitrinite. Therefore, the maturity of the samples in this paper is measured by the reflection of solid bitumen $(\mathrm{Rb})$ in both lower Cambrian and lower Silurian shales, and then the linear regression equation proposed by Jacob in 1985 [30]: Ro $=0.618 \mathrm{Rb}+0.4$, the equivalent vitrinite reflectance (Ro) will be gotten.

\subsection{Mineralogical Composition}

X-ray diffraction (XRD) patterns are used for mineralogical analysis of shale samples. Take $5 \mathrm{~g}$ of each sample separately, the sample will be broken and screened and separated, and the sample with 300 mesh size will be selected. Then, the slides required for the experiment were prepared, and the slides were coated with a solution of the sample mixed with ethanol. After the slides were fabricated, the experiment was performed using a Bruker D8 DISCOVER diffractometer at $45 \mathrm{kV}$ and $35 \mathrm{kV}$. The instrument was equipped with a Sol-X solid-state detector and a $\mathrm{Cu}$ x-ray tube. The measurement of mineral components is based on a principle of $\mathrm{K} \alpha$-radiation. It is important to set the room to $24{ }^{\circ} \mathrm{C}$ and $35 \%$ humidity, keep the scanning frequency at $20 \mathrm{~s} / 0.02^{\circ}$ step.

\section{3. $\mathrm{N}_{2}$ Adsorption}

As a conventional method to measure the pore size of bulk, $\mathrm{N}_{2}$ adsorption is mainly used to test the mesopore distribution characteristics of shale. Physical adsorption can occur on shale pore surface at low temperature, according to the theory of BET model, the PSA (pore surface area) of shale pore can be obtained at a relative pressure $\left(\mathrm{P} / \mathrm{P}_{0}\right)$ under $0.05-035$, which was analyzed by the principle of multi-layer adsorption. The pore volume of shale was obtained by measuring the amount of liquid nitrogen in the pores. The pore sizes corresponding to capillary condensation also differ from different relative pressures. The amount of liquid nitrogen with different pore sizes of different relative pressures can be equivalent to different pore volume, and then calculated through BJH model (BarretteeJoyneree-Halenda) [31]. In this paper, the analyzes of $\mathrm{N}_{2}$ adsorption was performed by a Micromeritics Tristar II 3020 SA analyzer under low-pressure $(<0.127 \mathrm{Mpa})$. Before the experiment, samples were crushed into appropriate particle size (60-80 mesh) and were put in liquid nitrogen, maintained a constant temperature at $77 \mathrm{k}$, then recording the amount of adsorption and desorption while increasing and decreasing relative pressure, respectively. Mapping adsorption-desorption curves corresponding to the records and determining the type of the pore, then the pore volume and PSA distribution can be obtained by selecting the corresponding pore calculation model.

\subsection{FIB-SEM}

The identification of the micro-matrix components and the observation of the nanoscale pores were facilitated by using Company FEI's FIB-SEM, Helios 650, which maximum resolution is $0.8 \mathrm{~nm}$. First, the bulk sample was mechanically polished and ground by a focused ion beam. Then, the conductivity should be strengthened by a Denton Desktop IV sputtering system coating an alloy of $\mathrm{Au} / \mathrm{Pd}$ to the surface of sample. Due to atomic number contrast in various mineral compositions, the image information of crystal orientation, grain boundary and microtexture can be explored under the condition of $1 \mathrm{kV}$ accelerating voltage by using backscattered electrons (BSE). The gray-scale variation of BSE images in various minerals shows differences of elemental atomic number, which can be used as indicators of mineralogy. In addition, secondary electrons at $20 \mathrm{kV}$ can significantly improve imaging resolution of nanoscale pores topography observation.

\section{Results}

\subsection{TOC and \% Ro}

Both lower Cambrian and lower Silurian shales were rich in oil-prone dispersed organic matter (e.g., amorphous OM). OM occurs in an amorphous state with light-gray under white light (Figure 2). Sapropelite shared $75 \mathrm{vol} \%$ of the total maceral content 
(Figure 3a), indicating that the OM of marine shale was of oil-prone type (type I kerogen). TOC of lower Cambrian shale samples range from 0.07 to $7.23 \%$, with an average of $3.9 \%$. In contrast, TOC of lower Silurian shales range from 0.92 to $4.57 \%$, with an average of $2.04 \%$ (Table 1). The proportion of TOC $>2 \%$ in lower Cambrian shale (accounting for $72.25 \%$ ) are higher than that of lower Silurian shale (accounting for 42.75\%) (Figure 3b). In addition, the $\%$ Ro values of both Cambrian and Silurain samples are in the over-thermal maturity stage. With an averaging value of $3.5 \%$ Ro, lower Cambrian shale experienced higher thermal and pressure degree than lower Silurian shale with averaging 2.69\% Ro (Table 1).
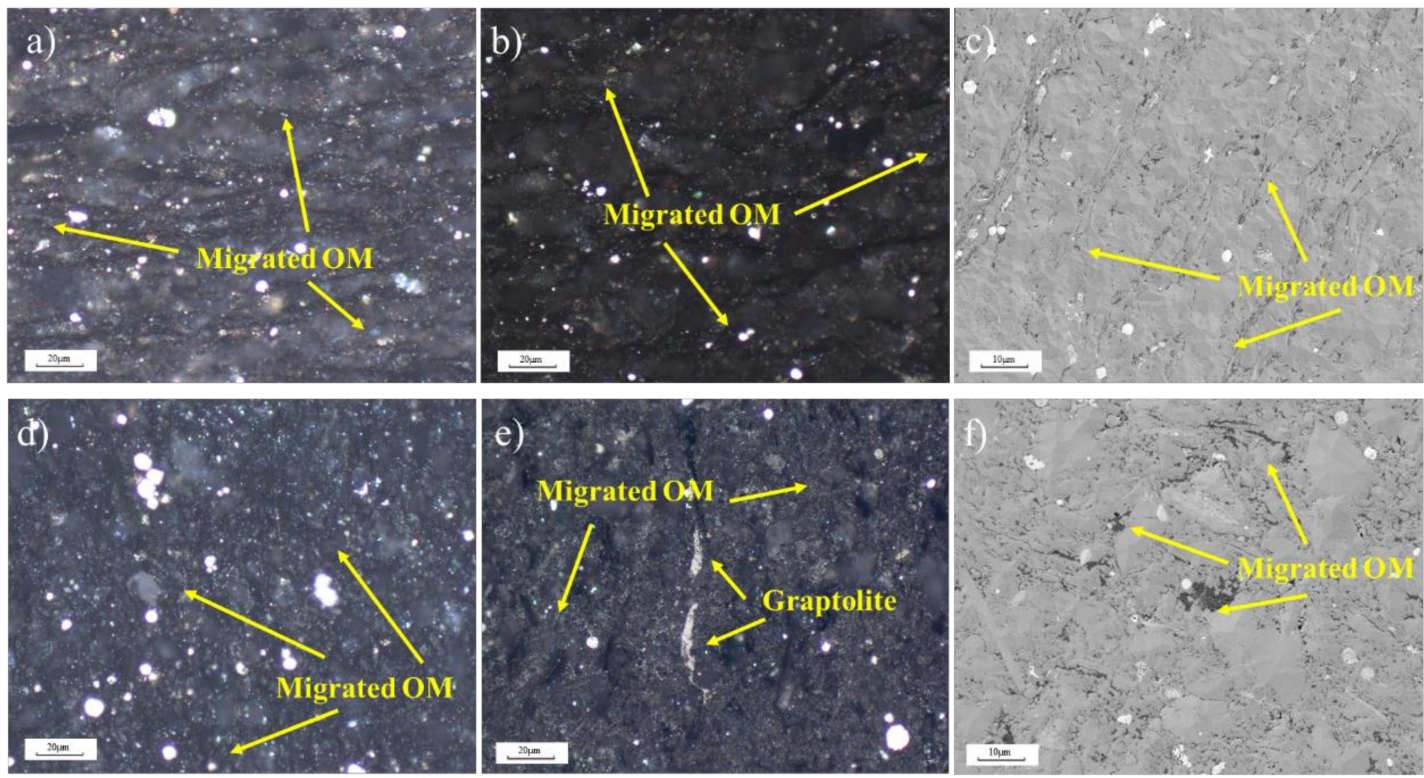

Figure 2. Morphological features of OM in marine shale. $(\mathbf{a}, \mathbf{b})$ in Lower Silurian shale, the OM occurs in an amorphous state that appears light-gray under white light (L1 and L2); (c) in lower Silurian shale, liptinite occur in fibrous or nodular shapes under FIB-SEM (L3); (d,e) in lower Cambrian shale, the OM occurs in an amorphous state that appears light-gray under white light (N3 and N4); (f) in lower Cambrian shale, liptinite occur in fibrous or nodular shapes under FIB-SEM (N4).
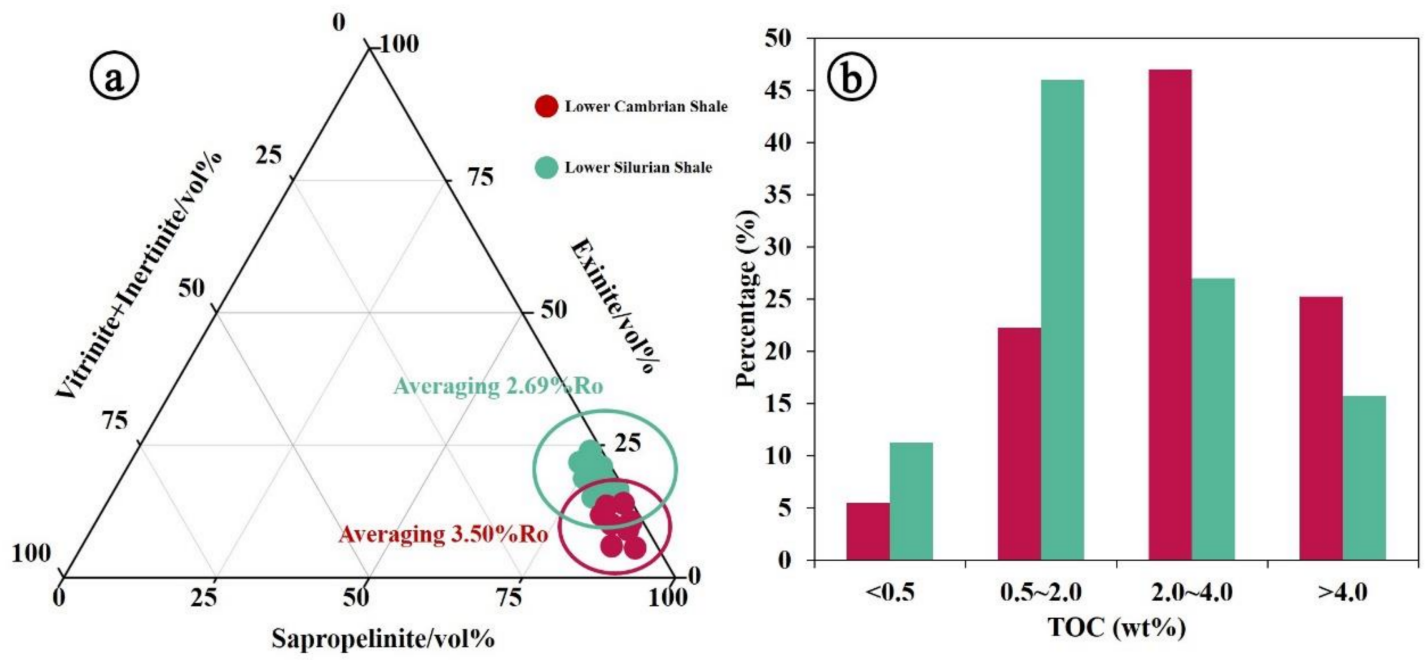

Figure 3. (a) Ternary plot of maceral compositions and thermal degrees. Sapropelite shared 75 vol $\%$ of the total maceral volume in both lower Cambrian shale and in lower Silurian shale, (b) histogram of TOC distribution in both lower Cambrian shale and in lower Silurian shale. 
Table 1. Geochemical characteristics, mineralogical compositions, and petrophysical parameters of shale samples from lower Cambrian shale and lower Silurian shale. (Note: \% Ro values are from solid bitumen in both studied shales).

\begin{tabular}{|c|c|c|c|c|c|c|c|c|c|c|}
\hline Samples & Sratigraphy & Wells & $\begin{array}{l}\text { Depth } \\
\text { (m) }\end{array}$ & $\begin{array}{c}\text { TOC } \\
(w t \%)\end{array}$ & $\operatorname{Ro}(\%)$ & $\begin{array}{l}\text { Quartz } \\
(w t \%)\end{array}$ & $\begin{array}{c}\text { Feldspar } \\
(w t \%)\end{array}$ & $\begin{array}{c}\text { Carbonate } \\
(w t \%)\end{array}$ & $\begin{array}{l}\text { Pyrite } \\
(w t \%)\end{array}$ & $\begin{array}{l}\text { Total } \\
\text { Clays } \\
(w t \%)\end{array}$ \\
\hline$\# 1$ & Cambrian & N1 & 447.5 & 2.74 & 3.06 & 36.6 & 14.1 & 25.9 & / & 23.4 \\
\hline$\# 2$ & Cambrian & N1 & 1149 & 3.26 & 3.33 & 39.1 & 11.5 & 20 & / & 29.4 \\
\hline$\# 3$ & Cambrian & N2 & 1448.9 & 5.76 & 3.59 & 34.3 & 8.8 & 12.6 & 3.2 & 37.1 \\
\hline$\# 4$ & Cambrian & N2 & 1457.6 & 7.01 & 3.54 & 60.8 & / & 0 & 7.4 & 31.8 \\
\hline$\# 5$ & Cambrian & N3 & 415 & 2.86 & 3.14 & 49.6 & 14.7 & 15.9 & 2.2 & 17.6 \\
\hline \#6 & Cambrian & N3 & 805 & 4.6 & 3.21 & 49.9 & 7.6 & 23.3 & 6.1 & 13.1 \\
\hline$\# 7$ & Cambrian & N4 & 1968 & 4.48 & 3.84 & 50.2 & 8.9 & 6.1 & 3.4 & 31.4 \\
\hline$\# 8$ & Cambrian & N4 & 1987.5 & 7.23 & 3.91 & 44.6 & 9.5 & 4.8 & 5.9 & 35.2 \\
\hline mean & & & & 4.7 & 3.5 & 45.6 & 10.7 & 13.6 & 4.7 & 27.4 \\
\hline \#9 & Silurian & L1 & 2330 & 2.07 & 2.5 & 55.6 & 6.1 & 5.8 & 6.1 & 26.4 \\
\hline$\# 10$ & Silurian & L1 & 2402.5 & 2.62 & 2.57 & 20.3 & 0 & 0 & 4.8 & 74.9 \\
\hline \#11 & Silurian & L1 & 2408.9 & 1.05 & 2.58 & 36.1 & 8 & 2.6 & 3.9 & 49.4 \\
\hline$\# 12$ & Silurian & L2 & 751 & 0.92 & 2.1 & 34 & 15.3 & 0 & 4.2 & 46.5 \\
\hline$\# 13$ & Silurian & L2 & 774.19 & 3.13 & 2.14 & 39.2 & 9.9 & 5.1 & 3.4 & 42.4 \\
\hline$\# 14$ & Silurian & L3 & 843.73 & 2.9 & 2.3 & 45.8 & 9.8 & 6.5 & 0 & 37.9 \\
\hline$\# 15$ & Silurian & L3 & 856.23 & 4.1 & 2.31 & 28.5 & 11 & 32.4 & 0 & 28.1 \\
\hline$\# 16$ & Silurian & $\mathrm{L} 4$ & 904.63 & 2.82 & 2.3 & 50.4 & 7.5 & 5.8 & 6.8 & 29.5 \\
\hline \#17 & Silurian & $\mathrm{L} 4$ & 907.43 & 4.57 & 2.13 & 60.5 & 7.7 & 8.5 & 2.8 & 20.5 \\
\hline mean & & & & 2.69 & 2.33 & 41.16 & 8.37 & 7.41 & 3.56 & 39.51 \\
\hline
\end{tabular}

\subsection{Mineral Components}

Both lower Cambrian and Silurian shale samples were dominated by siliceous components along with carbonate minerals (Table 1 and Figure 4). However, there are still some differences in mineral composition between lower Cambrian and Silurian shales. In detail, quartz and feldspar were dominated in lower Cambrian shale, which ranged from 43.1 to $64.3 \mathrm{wt} \%$, with an average of $56.3 \mathrm{wt} \%$. The content of clay mineral in the lower Cambrian shale was 13.1-37.1 wt \%, with an average of $27.4 \mathrm{wt} \%$ (Table 1 and Figure 4). In contrast, lower Silurian shale possessed a high content of clay, some of which were clay shale with values ranging from 20.5 to $74.9 \mathrm{wt} \%$ (an average of $39.51 \mathrm{wt} \%$ ). Quartz and feldspar ranged from 20.3 to $68.2 \mathrm{wt} \%$, with an average of $49.53 \mathrm{wt} \%$ (Table 1 and Figure 4). Additionally, pyrite was identified as minor phase in either lower Cambrian shale or lower Silurian shale, with values of $4.70 \mathrm{wt} \%$ and $3.56 \mathrm{wt} \%$, respectively (Table 1 ).
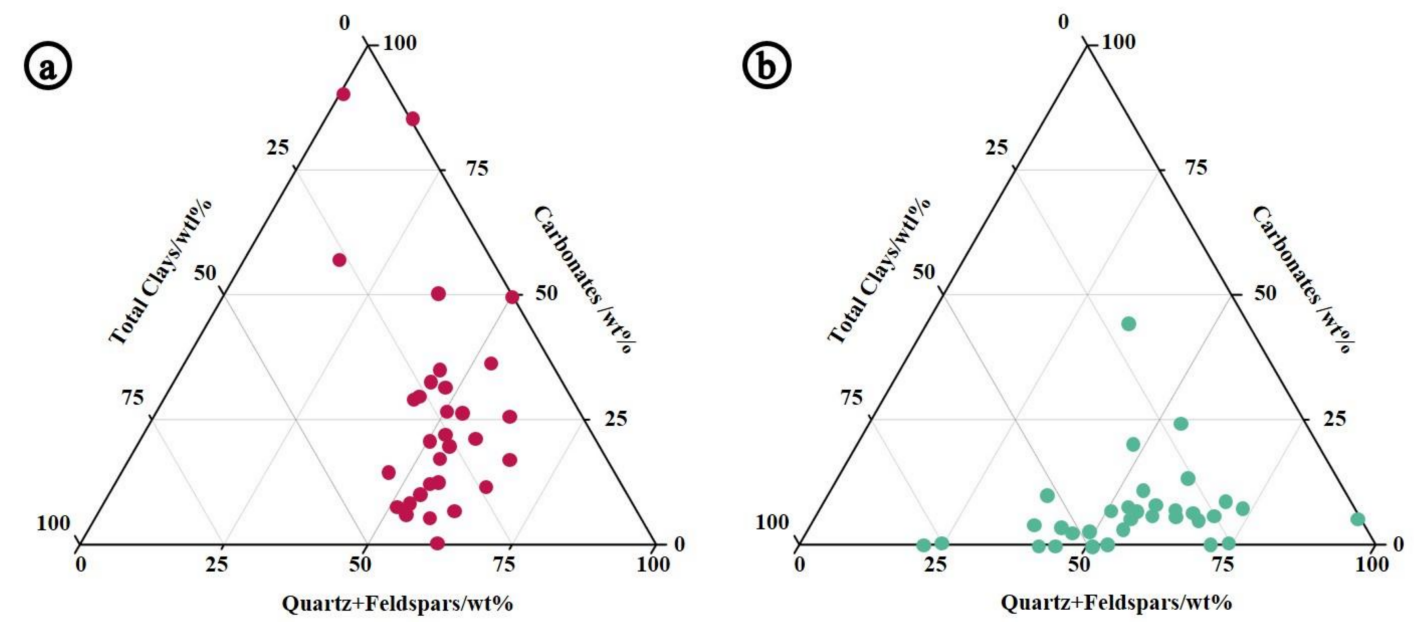

Figure 4. Mineralogical ternary plot for shale samples: (a) samples of lower Cambrian shale are represented by the red dots and (b) samples of lower Silurian shale are represented by the green dots. 


\subsection{Pore Volumes and Pore Surface Areas}

Lower Cambrian shale possessed low PV (avg. $0.015 \mathrm{~mL} / \mathrm{g}$ ) and PSA (avg. $9.49 \mathrm{~m}^{2} / \mathrm{g}$ ) (Table 2 and Figures 5 and 6). PV was mainly contributed by mesopores sharing 59\% of the total, and PSA was mainly provided by micropores and mesopores both sharing $50 \%$ of the total (Table 2 and Figures 5 and 6). In contrast, lower Silurian shale possessed high PV and PSA, with averaging $0.025 \mathrm{~mL} / \mathrm{g}$ and $25.16 \mathrm{~m}^{2} / \mathrm{g}$, respectively (Table 2 and Figures 5 and 6). PV was mainly contributed by mesopores sharing $74 \%$ of the total, and PSA was mainly provided by micropores and mesopores both sharing $50 \%$ of the total (Table 2 and Figures 5 and 6). Comparatively, PV of lower Silurian shale was approximately 1.5 times higher than that of lower Cambrian shale, and PSA of lower Silurian shale was almost 2.5 times higher than that of lower Cambrian shale (Table 2).

Table 2. The PVs, surface areas, and the corresponding proportions of Lower Cambrian shale and Lower Silurian shale analyzed by $\mathrm{N}_{2}$ adsorption experiments.

\begin{tabular}{|c|c|c|c|c|c|c|c|c|c|c|c|c|c|c|c|c|}
\hline \multirow{2}{*}{ Samples } & \multirow{2}{*}{ Wells } & \multirow{2}{*}{$\begin{array}{c}\text { Depth } \\
\text { (m) }\end{array}$} & \multicolumn{3}{|c|}{ Pore Volume (mL/g) } & \multirow{2}{*}{$\begin{array}{l}\text { Total } \\
\text { PV }\end{array}$} & \multicolumn{3}{|c|}{ Proportion (\%) } & \multicolumn{3}{|c|}{ Pore Surface Area $\left(\mathrm{m}^{2} / \mathrm{g}\right)$} & \multirow{2}{*}{$\begin{array}{c}\text { Total } \\
\text { PSA }\end{array}$} & \multicolumn{3}{|c|}{ Proportion (\%) } \\
\hline & & & Micropore & Mesopore & Macropore & & Micropore & Mesopore & Macropore & Micropore & Mesopore & Macropore & & Micropore & Mesopore & Macropore \\
\hline \#1 & N1 & 448 & 0.001 & 0.009 & 0.003 & 0.014 & 10 & 68 & 21 & 3.84 & 5.36 & 0.10 & 9.30 & 41 & 58 & 1 \\
\hline \#2 & N1 & 1149 & 0.002 & 0.008 & 0.003 & 0.013 & 12 & 61 & 26 & 4.02 & 4.32 & 0.09 & 8.43 & 48 & 51 & 1 \\
\hline$\# 3$ & $\mathrm{~N} 2$ & 1449 & 0.003 & 0.011 & 0.004 & 0.018 & 17 & 59 & 24 & 4.76 & 5.23 & 0.12 & 10.11 & 47 & 52 & 1 \\
\hline$\# 4$ & $\mathrm{~N} 2$ & 1458 & 0.003 & 0.007 & 0.004 & 0.014 & 20 & 52 & 28 & 4.52 & 4.27 & 0.11 & 8.89 & 51 & 48 & 1 \\
\hline \#5 & N3 & 415 & 0.002 & 0.007 & 0.002 & 0.011 & 21 & 60 & 19 & 4.27 & 4.27 & 0.16 & 8.71 & 49 & 49 & 2 \\
\hline$\# 6$ & N3 & 805 & 0.003 & 0.009 & 0.003 & 0.016 & 22 & 60 & 18 & 4.76 & 4.86 & 0.09 & 9.71 & 49 & 50 & 1 \\
\hline \#7 & $\mathrm{N} 4$ & 1968 & 0.003 & 0.010 & 0.004 & 0.017 & 18 & 56 & 26 & 5.07 & 4.27 & 0.13 & 9.46 & 54 & 45 & 1 \\
\hline$\# 8$ & N4 & 1988 & 0.004 & 0.010 & 0.004 & 0.018 & 23 & 55 & 22 & 6.00 & 5.18 & 0.11 & 11.30 & 53 & 46 & 1 \\
\hline mean & & & 0.003 & 0.009 & 0.003 & 0.015 & 18 & 59 & 23 & 4.65 & 4.72 & 0.11 & 9.49 & 49 & 50 & 1 \\
\hline$\# 9$ & L1 & 2330 & 0.005 & 0.020 & 0.004 & 0.029 & 16 & 70 & 14 & 14.42 & 13.69 & 0.20 & 28.32 & 51 & 48 & 1 \\
\hline$\# 10$ & L1 & 2403 & 0.003 & 0.017 & 0.002 & 0.021 & 12 & 77 & 11 & 13.51 & 12.33 & 0.15 & 25.99 & 52 & 47 & 1 \\
\hline$\# 11$ & L1 & 2409 & 0.002 & 0.015 & 0.002 & 0.020 & 12 & 78 & 9 & 10.15 & 10.48 & 0.14 & 20.77 & 49 & 50 & 1 \\
\hline$\# 12$ & L2 & 751 & 0.002 & 0.013 & 0.002 & 0.016 & 10 & 78 & 12 & 5.49 & 7.78 & 0.14 & 13.41 & 41 & 58 & 1 \\
\hline$\# 13$ & L2 & 774 & 0.005 & 0.022 & 0.003 & 0.030 & 17 & 72 & 11 & 15.63 & 14.01 & 0.28 & 29.92 & 52 & 47 & 1 \\
\hline$\# 14$ & L3 & 844 & 0.004 & 0.018 & 0.003 & 0.024 & 16 & 74 & 11 & 11.02 & 11.81 & 0.19 & 23.02 & 48 & 51 & 1 \\
\hline$\# 15$ & L3 & 856 & 0.004 & 0.023 & 0.004 & 0.031 & 13 & 74 & 13 & 13.92 & 14.41 & 0.39 & 28.71 & 49 & 50 & 1 \\
\hline$\# 16$ & L4 & 905 & 0.003 & 0.018 & 0.003 & 0.024 & 11 & 76 & 14 & 9.93 & 11.56 & 0.34 & 21.82 & 46 & 53 & 2 \\
\hline$\# 17$ & L4 & 907 & 0.005 & 0.025 & 0.004 & 0.034 & 15 & 73 & 12 & 16.79 & 17.46 & 0.25 & 34.50 & 49 & 51 & 1 \\
\hline mean & & & 0.004 & 0.019 & 0.003 & 0.025 & 14 & 74 & 12 & 12.32 & 12.61 & 0.23 & 25.16 & 49 & 50 & 1 \\
\hline
\end{tabular}
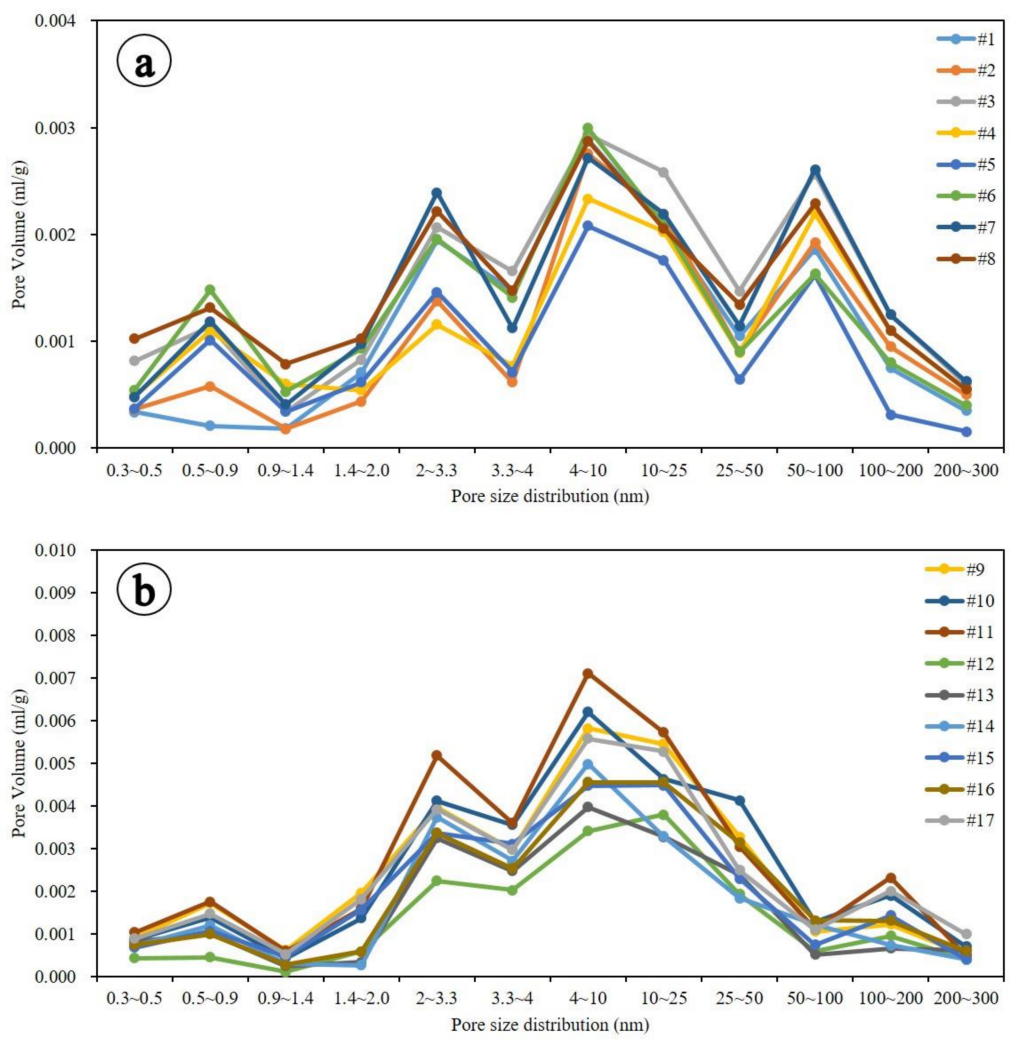

Figure 5. The PVs of lower Cambrian shale and lower Silurian shale analyzed by $\mathrm{N}_{2}$ adsorption experiments: (a) PVs of lower Cambrian shale samples (\#1-\#8) and (b) PVs of lower Silurian shale samples (\#9-\#17). 

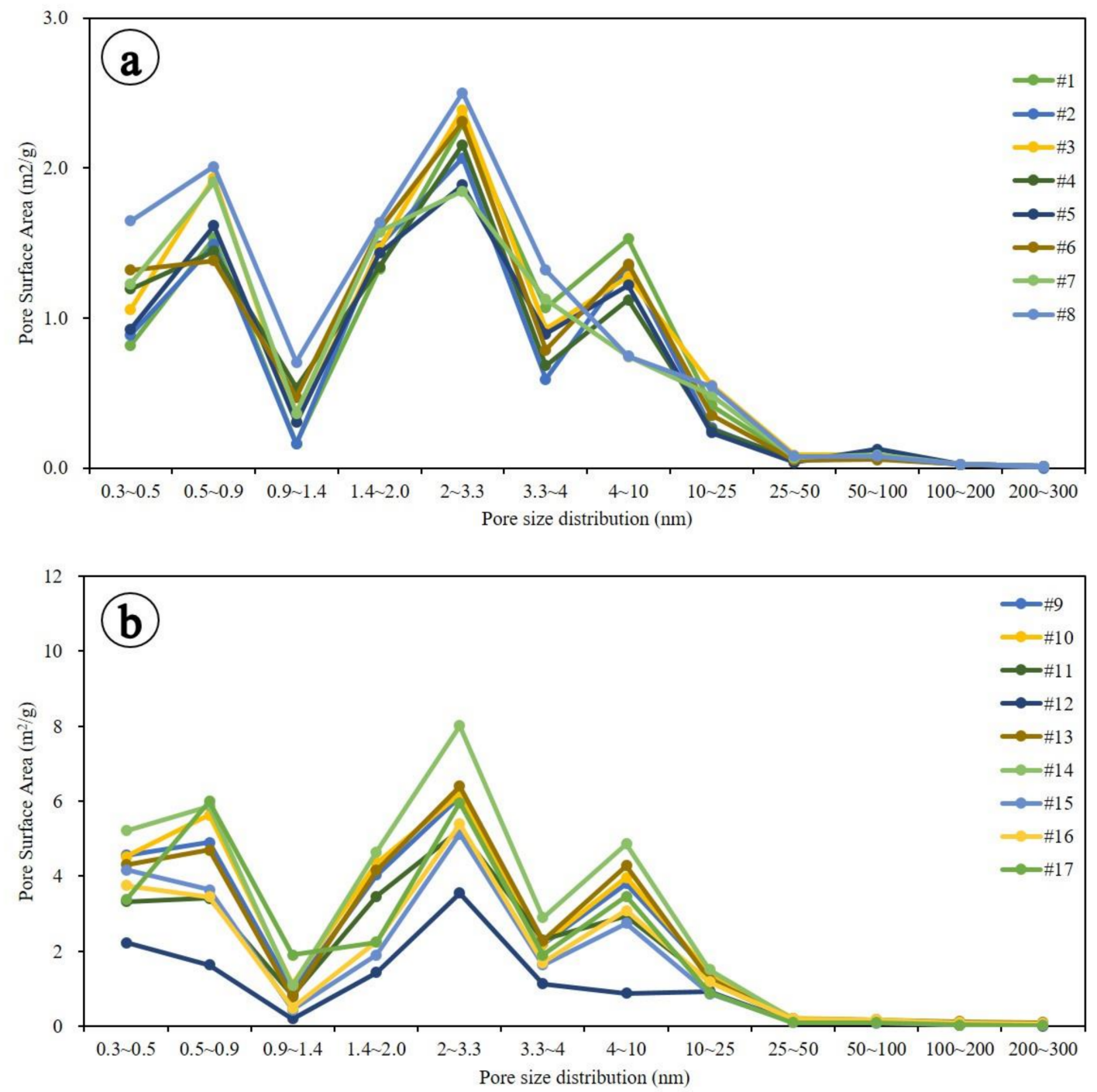

Figure 6. The PSAs of lower Cambrian shale and lower Silurian shale samples analyzed by $\mathrm{N}_{2}$ adsorption experiments: (a) PVs of lower Cambrian shale samples (\#1-\#8) and (b) PSAs of lower Silurian shale samples (\#9-\#17).

\subsection{Morphology Features of Matrix-Related Pores}

Four distinctive pore types were recognized from both studied shales: pores of mineral framework, pores associated with clay minerals, dissolved pores and OM-hosted pores through direct observation of FIB-SEM imaging. Of note, micro-fractures were excluded from this research. The classification of pore types is based on the related matrixes in terms of brittle minerals, clay sheets, soluble minerals and OM. Pores are spaces confined by inorganic minerals and OM, which can transform either mechanically or chemically corresponding to the changing of temperature and pressure condition in situ gas-bearing shale. Therefore, the shale matrixes may be the straightest control on the pore space, and this classification can be beneficial to the dynamic analysis from the perspective of pores origins.

Pores of mineral framework develop at edges of rigid grains (Figure 7a-d). This type of pore is a kind of residual pore after compaction that is often associated with quartz, calcite and pyrite with high brittleness [32]. The frame can be built by the convex contact of rigid grains and pores located at concave points with varied sizes and irregular figures. There is no difference between the two formations in terms of pores of mineral framework. It should be mentioned that the crack in Figure 7e,f is a shrinkage crack and probably does not exist under in situ conditions. 

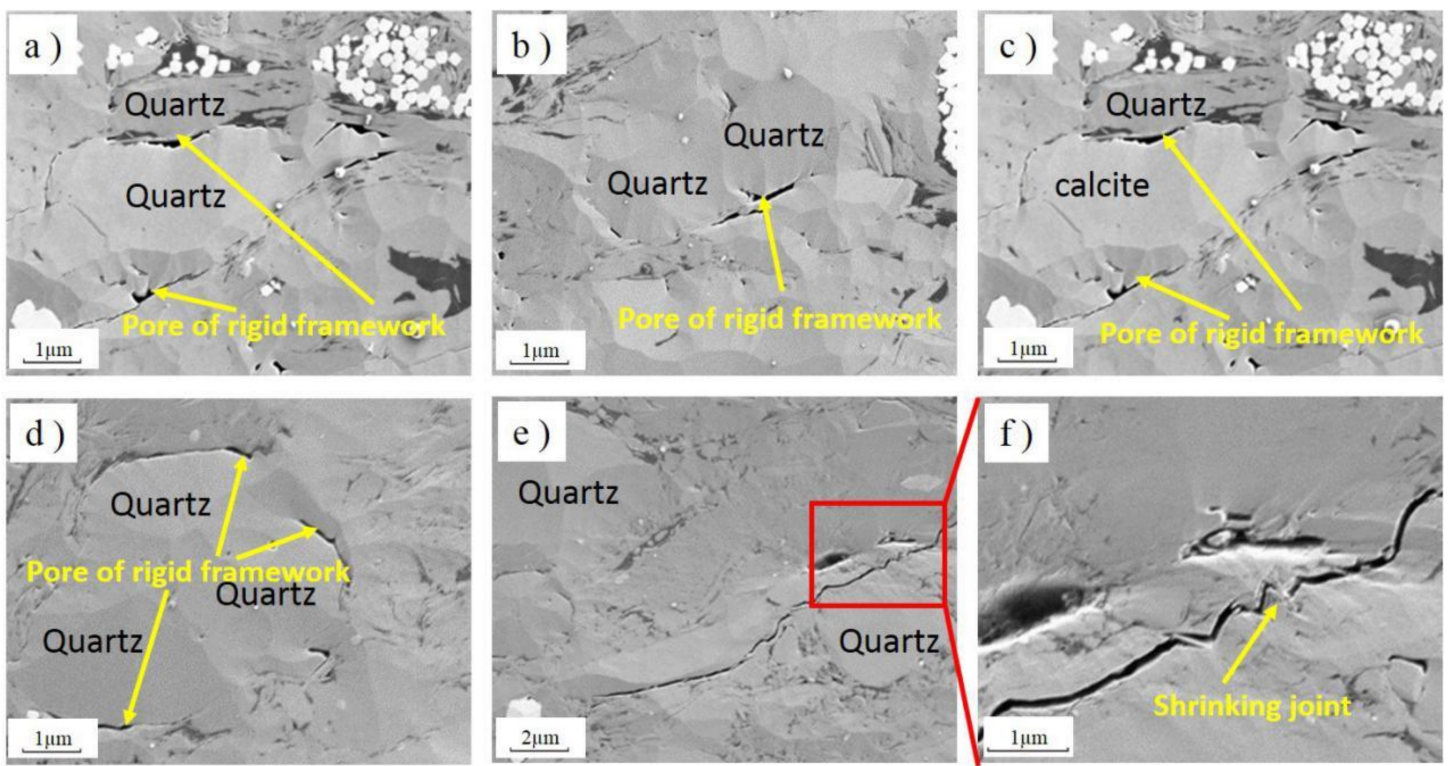

Figure 7. The FIB-SEM 2D images of pores of rigid framework: Pores are marked by the yellow arrows. (a-c) are \#1, \#2 and \#3 samples of the lower Cambrian shale. (d-f) are \#10 and \#13 samples of the lower Silurian shale. In $(\mathbf{e}, \mathbf{f})$, the crack is a shrinkage crack and should not exist under formation conditions (\#12).

Pores associated with clay minerals are bound by clay flakes (Figure 8a-h). The preferential orientation of these clay mineral flakes is rarely shown, the pores are generally flaky and elongated due to the accumulation of non-directional clay in both shales. (Figure 8a). Some pores can be retained due to the relatively gentle compaction of rigid particles such as pyrite and calcite, which formed in the transformation of clay minerals (Figure $8 b, c)$. In another case, pores cannot be observed in the thin sheets (Figure 8d) owing to the strong compaction of lower Cambrian shale. In comparison, the clay flakes in lower Silurian shale can be observed and the pores are filled with migrated organic matter, which formed a few secondary OM-hosted pores during the hydrocarbon generation stage (Figure $8 \mathrm{e}-\mathrm{h}$ ). In addition, mini-crystal quartz and pyrite insert in the clay flakes, which can be also identified through Figure 8e-h.
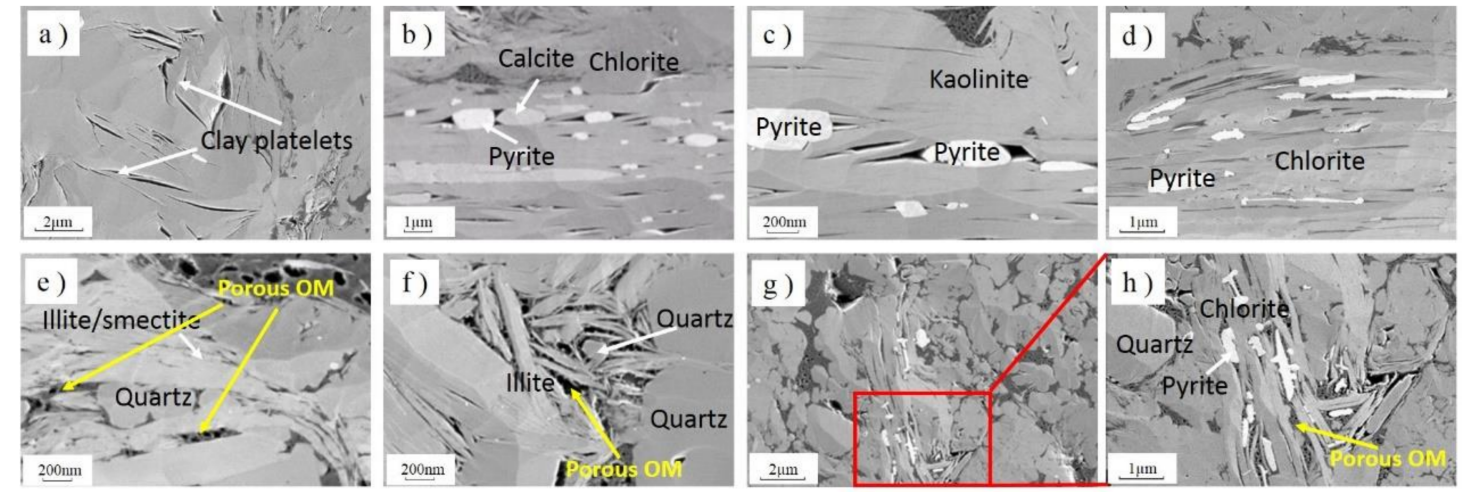

Figure 8. The FIB-SEM 2D images of pores associated with clay mineral flakes: Some minerals are marked by white arrows and porous OM with yellow arrows. (a-d) are \#2, \#4, \#5 and \#7 samples of the lower Cambrian shale. (e-h) are \#9, \#11 and \#15 samples of the lower Silurian shale.

Generally, the majority of dissolved pores are related to carbonate minerals (Figure 9). According to the observation of FIB-SEM image, it is found that dissolved pores are usually located on the surface of soluble particles (Figure 9a-f). In the case of lower Cambrian 
shale, dissolved pores present as isolated dot-like features (Figure 9a-c). While dissolved pores of lower Silurian shale show irregular serrated shapes around the edge of the particles (Figure $9 \mathrm{~d}-\mathrm{f}$ ). The dissolved mineral component can be either original sediments or reprecipitation of material (early cementation), which can be hard to determine by FIB-SEM.
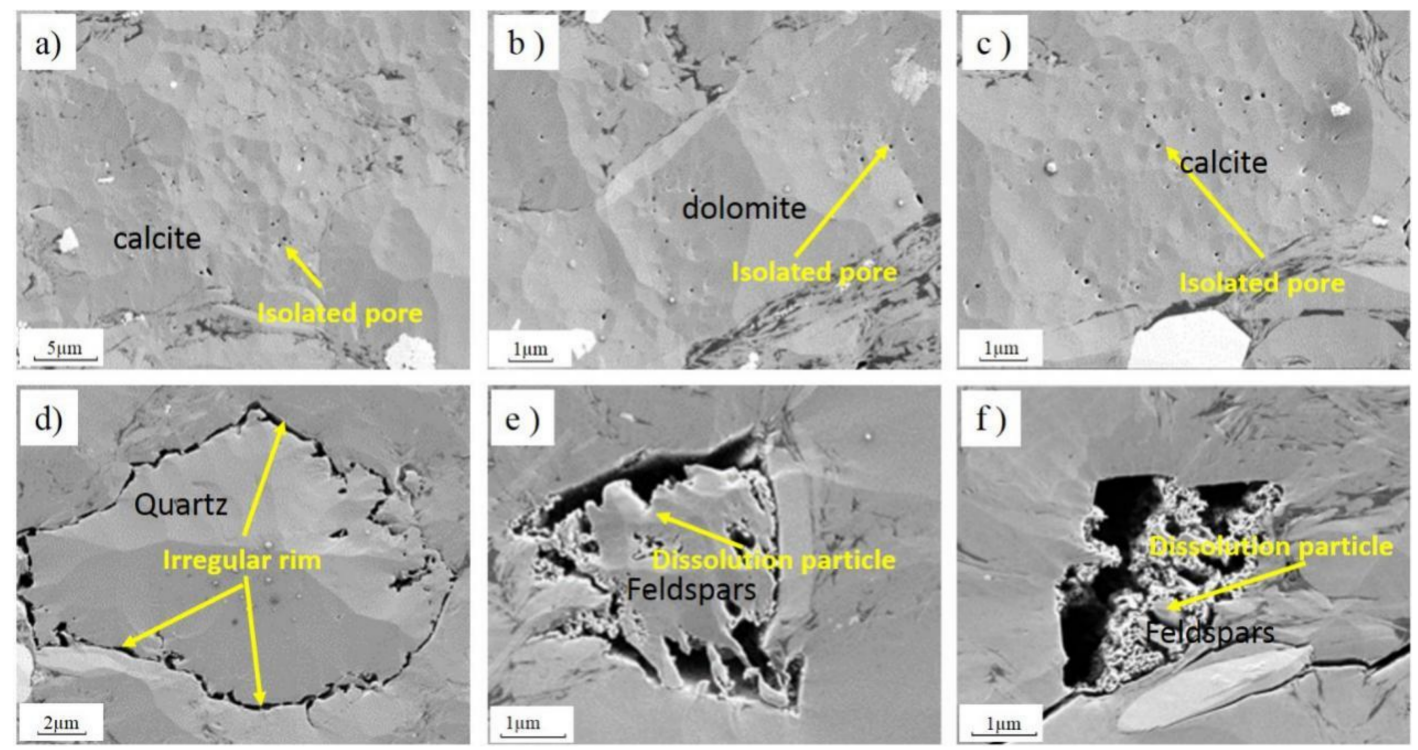

Figure 9. The FIB-SEM 2D images of dissolved pores: (a-c) isolated pores of the \#1 \#3 and \#6 samples of the lower Cambrian shale. (d-f) Pores with irregular rim and dissolution particle of the \#11 \#12 and \#16 samples of lower Silurian shale.

OM-hosted pores show large heterogeneity for both shapes and sizes in two sets of shale (Figure 10). Shapes can vary from a particle (Figure 10a,b,e,f) to strip and cement between grains or inside of pyrite framboids or clay platelets (Figure 10c-h). One single OM particle can contain hundreds of nanopores in lower Silurian shale (Figure 10e,f). While under the $2 \mathrm{~nm}$ theoretical resolution, porous features cannot be observed in lower Cambrian shale (Figure 10a,b). Furthermore, porous characteristics of OM inside of pyrite framboids are distinctively different between lower Cambrian shale (non-porous OM in Figure 10c,d) and lower Silurian shale (porous OM in Figure 10e,f). In the case of pore diameter, OM-hosted pores inside of pyrite framboids (Figure 10g,h) are larger than those of OM particles (Figure 10e,f) in Lower Silurian shale. Generally, the OM-hosted pores of lower Silurian shale (Figure 10e-h) have a larger diameter and a wider distribution (Figure 10a-d) than that of lower Cambrian shale, which are almost non-porous.
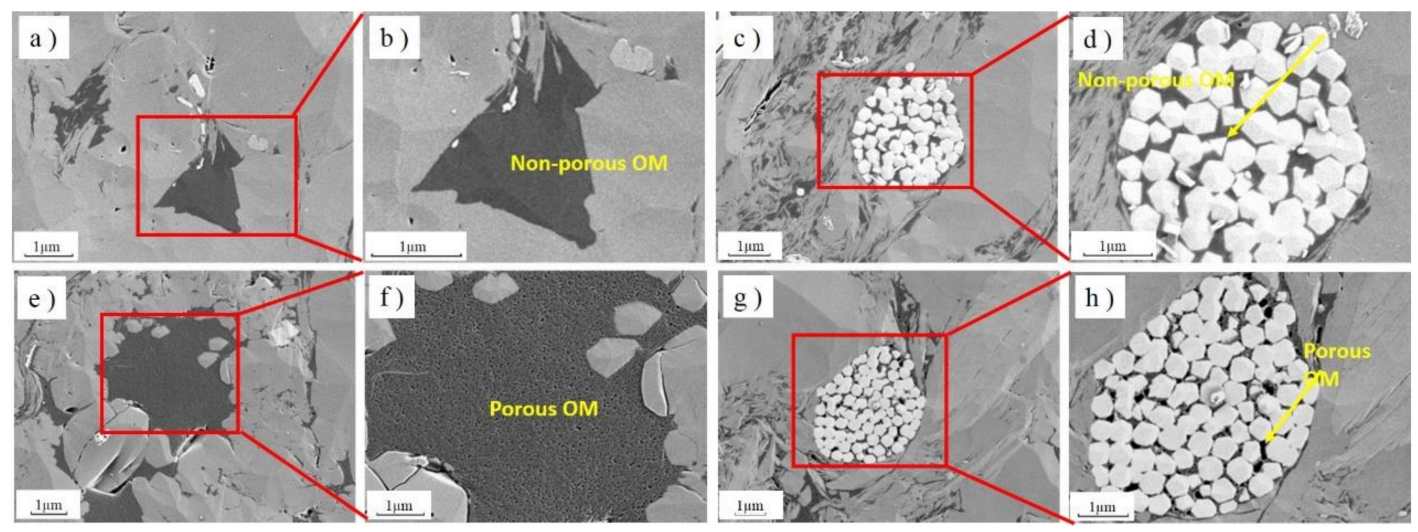

Figure 10. The FIB-SEM 2D images of OM-host pores and bulk OM: (a-d) are \#3 and \#5 samples of the lower Cambrian shale. (e-h) are \#14 and \#16 samples of the lower Silurian shale. 


\section{Discussion}

\subsection{Porosity Differences between the Two Shales}

The physical properties are quite different between studied shale samples. $\mathrm{N}_{2}$ adsorption measured by NMR showed that PV and PSA were similar within lower Cambrian or lower Silurian shale samples, while notable differences were detected between lower Cambrian and lower Silurian shale samples (Figures 5 and 6). Additionally, physical properties of lower Silurian shale samples are higher than those of lower Cambrian shale samples. Relationships among PV, PSA and TOC present strong correlation in lower Silurian shale samples rather than in lower Cambrian shale samples (Figure 11). This means that OM is the main contributor of pore space in lower Silurian shale samples. On the other hand, relationships between PV (PSA) and minerals (siliceous, clay and carbonate components) present irrelative correlation in both lower Silurian and lower Cambrian shales (Figure 12). This means that minerals cannot provide pore space with little influence on reservoir properties.
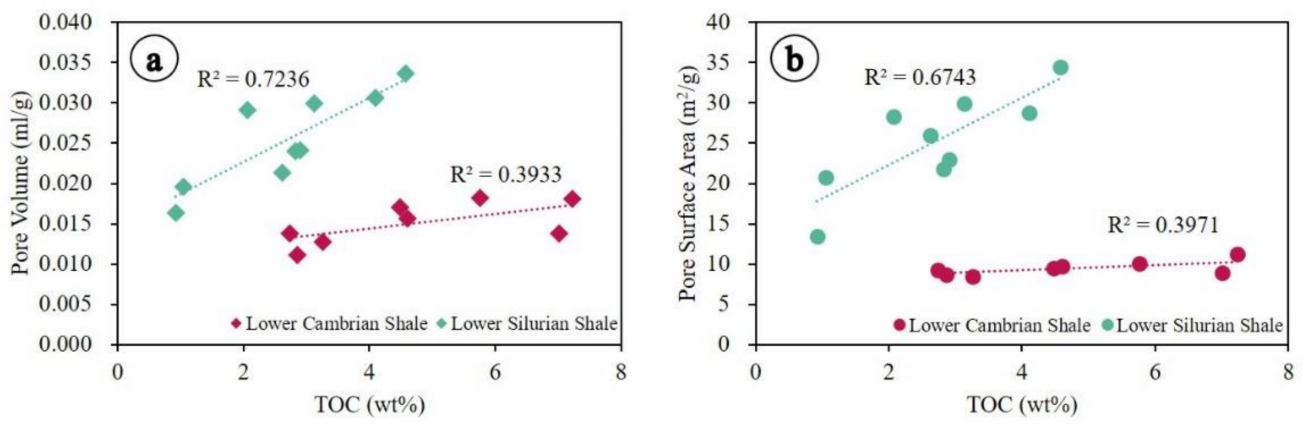

Figure 11. Scatter charts of correlations between pore properties and TOC. (a) Relationship between pore volume and TOC in both lower Cambrian shale and in Lower Silurian shale; and (b) relationship between pore surface area and TOC in both lower Cambrian shale and in lower Silurian shale.

Pore capacities of OM and minerals in the two shales can be manifested by observation under FIB-SEM (Figure 10). Porous OMs distribute widely in lower Silurian shale, while OMs in lower Cambrian shale are generally non-porous. Additionally, pores associated with minerals are scatter and isolated in both of the two shale (Figures 7-9). Majority of pore space are occupied by OM and diagenetic cements. Therefore, OM-hosted pore is the dominant pore type and contributes PV and PSA in Lower Silurian shale (Figures 5 and 6), while no matrix can provide enough pores in Lower Cambrian shale, which present low PV and PSA (Figures 5 and 6). Lower Cambrian shale and Lower Silurian shale possess similar materials, but distinctive thermal degrees. Evolution mechanism of different types of pores, especially OM-hosted pores, may trigger this different pore features.

\subsection{Evolution Mechanism of Different Types of Pores}

Pores of rigid framework are the residue of primary interparticle pores during the burial history, which can be searched through FIB-SEM (Figure 7). On the circumstance of original sedimentary, the dominant pore type was the inter-particle pore locating among grains. Due to mechanical compaction, sedimentary grains re-arranged and transformed from spot-line to concave-convex during the history of burial. In this period, 80 90\% porosity destroyed and eliminated due to the compaction [33-35]. With the increasing effective pressure, the primary pore space decreased further owing to the deformation and injection of ductile matrixes (OM and clay) [36]. Moreover, chemical cementation forming through the dissolution-reprecipitation process and OM injection during the thermal evolution made pore space further reduce and rarely left [37] with less than $5 \%$ porosity left $[34,35]$. 

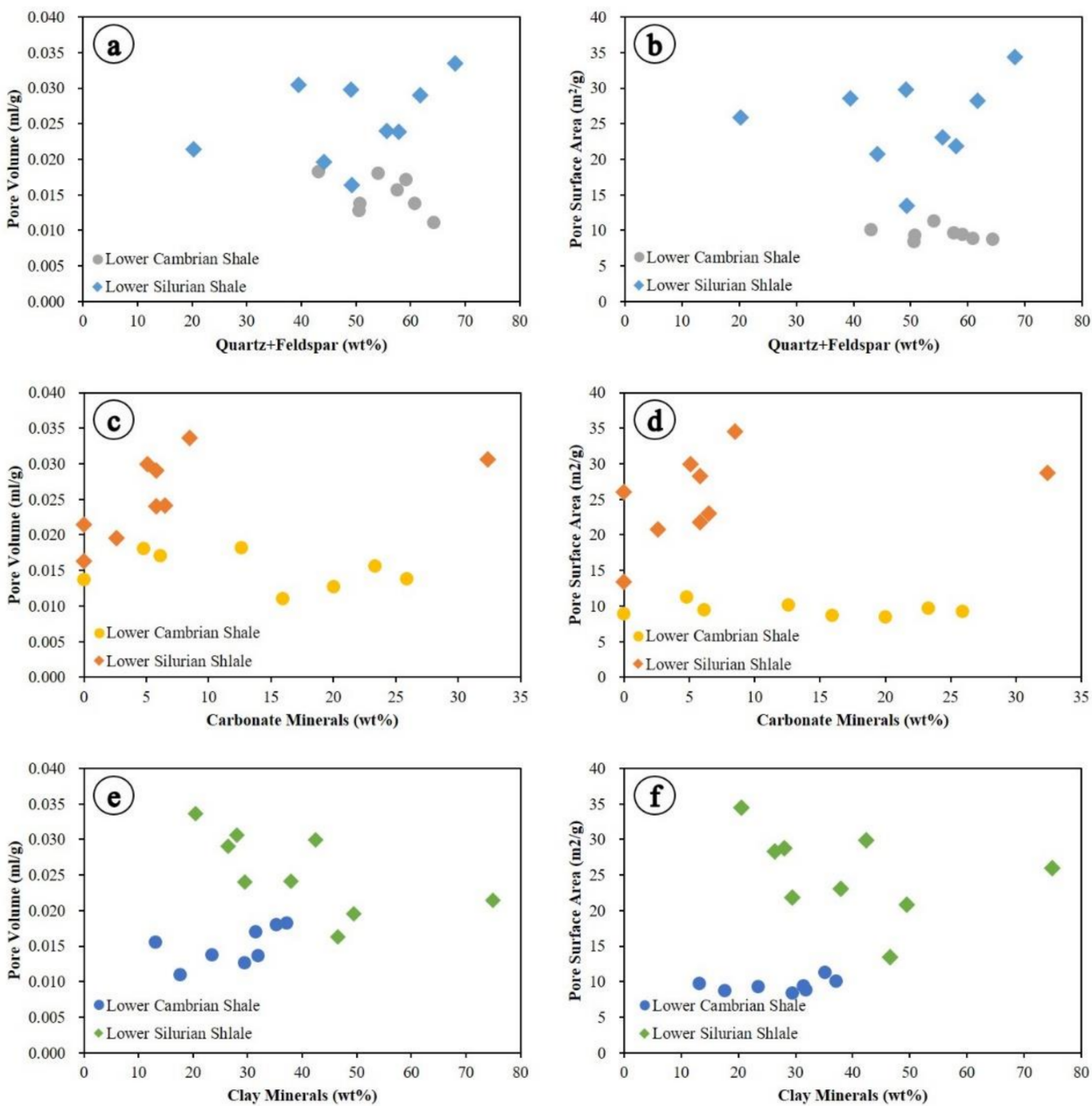

Figure 12. Scatter charts of correlations between pore properties and minerals. (a) relationship between pore volumes and Quartz + Feldspar; (b) relationship between pore surface areas and Quartz + Feldspar; (c) relationship between pore volumes and Carbonate minerals; (d) relationship between pore surface areas and Carbonate minerals; (e) relationship between pore volumes and Clay minerals; (f) relationship between pore surface areas and Clay minerals.

Pores associated with clay flakes, a kind of secondary pore type, develops via clay minerals transformation (plane collapse and contraction) [38,39]. With ductile nature, clay minerals tend to deform under overlap compaction. Some pores can be preserved adjacent to rigid grains (Figure 8). Micro-crystal minerals re-precipitating among clay flakes can also act as grain supporter, as quartz, pyrite and calcite. Moreover, randomly oriented clay platelets can build "Card-house structure" $[2,40]$ and preserve pores.

Dissolved pores (generally associated with carbonate minerals) can be observed on edges and surfaces of particles as isolated end-open holes or irregular rims (Figure 9) [12,41]. In the process of dissolved pore shaping, carbonate minerals react with acidic fluids (mainly organic acids generated before or during the period of the hydrocarbon generation), and reach a chemical equilibrium after exchange between the matrix and fluid materials. Due to low content of carbonate minerals, dissolved pores generally scatter within matrixes and contribute barely to porosity and permeability.

OM-hosted pores generate accompany with hydrocarbon generation. With increasing temperature and pressure, the phase of OM transforms from solid to liquid and gas, and OM-hosted pore develop on the surface of OM particles (Figure 10). OM can be divided into two types: depositional OM and OM by-product [37]. OM by-products refer to oil, bitumen and pyributumen and are more pore capacity than depositional OM, which was in agreement with many studies $[2,4,7,9]$. More importantly, both excessive OM content 
and over thermal maturity are detrimental to OM-hosted pores development [42,43], since $\mathrm{OM}$ presents as ductile nature which cannot resistant the overlying overpressure and acts as carbonation properties when temperature and pressure excess.

\subsection{Mechanic and Chemical Stability of Matrixes}

Rigid particles, clay flakes, and OM commonly co-exist within shale matrix. Rigid grains act as supporters, clay flakes confine ample space and OM first migrates into and provides secondary OM-hosted pores (Figures 7,8 and 10). In this condition, pores can be preserved owing to associating matrix with good mechanic and chemical stability.

Mechanic stability depends on whether pore carriers can resist compaction or surrounded by rigid anti-compacting particles (Figures 7, 8 and 10). Rigid particles can withstand overlying pressure and protect pore and ductile matrix from collapse and deformation [17,32]. More brittle minerals can possess more mechanic stability, and pores can be preserved from overlying compaction. On the other hand, over-pressure can enhance mechanic stability via taking over the overlying pressure [2]. A high gas content can also protect pores from compaction. Therefore, from the prospective of original sediments, bio-genetic siliceous lithofacies are conducive to high reservoir capacity, which possess rich brittle components for pore preservation and abundant OM for gas generation.

Chemical stability determines the degree of cements within pore space. The waterrock interaction of the matrix causes the exchange of fluids as well as the dissolution and precipitation of minerals [37]. Dissolution occurred in the high pressure zone, while the precipitation happened in the low pressure zone. Diagenetic cements precipitated in voids among particles, resulting into a decrease in reservoir porosity. Dissolved pores are mostly isolated pores or dead-end pores with poor connectivity (Figure 9), whereas saluted ions re-precipitate in the low pressure zone (pore space with good connectivity), resulting in a decrease in pore permeability and thus a limited contribution to the capacity of pore properties. Meanwhile, pore space of inorganic minerals may be filled with migrated OM (Figures 7,8 and 10). With lipophilic property, migrated OM occupies pore associated with inorganic minerals, where water-rock interactions are less likely to occur.

\subsection{Preserved Mechanisms of OM-Hosted Pores in Two Sets of Shales}

$\mathrm{OM}$ of two formations are both derived from oil-prone kerogen, and minerals are mainly siliceous and argillaceous components. However, pore features in two sets of studied shale samples are quite different. In the case of lower Cambrian shale, the gas generating ability and the micro-region gas content were reduced at excessively high $($ Ro $>3.5 \%$ ). Gas escaped through the connecting channel of pre-existing OM-mineral networks. The over-pressure environment in the micro-area was lost and the OM pore (main contributor of pore system) became smaller or even completely destroyed. The thermal degree of lower Silurian shale was suitable $(2.5 \% \mathrm{Ro})$ in the dry gas window, and the ability of gas generation might be still existed. The over-pressure of the micro-area can resist owing to adequate supply of gas origin, and OM-hosted pores can be preserved from compaction. Gas contents are quite different between lower Silurian shale and lower Cambrian shale, and the former is nearly 10 times higher than that of the latter [44]. The key factor of this difference is geological diversity.

An un-conformity exists at the bottom of the Cambrian Formation (Figure 1b), which is formed in Tongwan tectonic movement. It is the preferential migration passage of gaseous hydrocarbon generated from the upper shale systems. The long-term, continuous and extensive hydrocarbon expulsion results in low gas content within the Lower Cambrian shale. Consequently, gas pressure cannot share the overburden, and OM-hosted pores, once developed in the geological history, destroyed through compact deformation. On the contrary, shale system of lower Silurian shale possesses good sealing ability with tight overlying and underlying rocks (Figure 1b). Majority of hydrocarbon generated at either the peak of oil generation or the peak of gas generation cannot expel out of the shale system with weak historical hydrocarbon expulsion. Gas pressure is relatively high owing to the 
excessive amount of residue gas, which makes a positive contribution to pore preservation, especially OM-hosted pores with ductile nature.

The significant differences of structural settings result into various hydrocarbon explosion efficiency and different pressure circumstance, which consequently leads to the different pore features between the studied shale samples. For lower Cambrian shale, overpressure circumstance diminish if hydrocarbon expels outside of the shale system, and OM-hosted pores destroy through compaction. In Silurian shale, sustaining overpressure and abundant residue hydrocarbon (migrated $\mathrm{OM}$ ) make positive contributions to the pore properties, in terms of numbers, diameters and connectivity.

\section{Conclusions}

Lower Cambrian shale and lower Silurian shale are both typical of oil-prone kerogen and siliceous composition, but different in thermal maturities. PV of lower Silurian shale was approximately 1.5 times higher than that of lower Cambrian shale, and PSA of Lower Silurian shale was almost 2.5 times higher than that of lower Cambrian shale. Lower Cambrian shale and lower Silurian shale possess similar materials but distinctive thermal degrees. Evolution mechanisms of different types of pores, especially OM-hosted pores, may trigger this different pore features.

On the other hand, various hydrocarbon explosion efficiency and different pressure circumstance are caused by the differences of structural settings, which consequently leads to the different pore features between the two shales. For lower Cambrian shale, overpressure circumstance diminish if hydrocarbon expels outside of the shale system, and OM-hosted pores destroy through compaction. In Silurian shale, sustaining overpressure and abundant residue hydrocarbon (migrated $\mathrm{OM}$ ) make positive contributions to the pore properties, in terms of numbers, diameters and connectivity.

Author Contributions: Conceptualization, L.G. and M.L. (Minghui Li); methodology, M.L. (Mingliang Li); formal analysis, M.L. (Mingliang Li); investigation, M.L. (Mingliang Li); resources, H.H.; data curation, D.Z.; writing — original draft preparation, M.L. (Mingliang Li); writing—review and editing, M.L. (Mingliang Li); visualization, L.G.; funding acquisition, M.L. (Mingliang Li) All authors have read and agreed to the published version of the manuscript.

Funding: This research was funded by National Science and Technology Major Project, grant number No. 2017ZX05035-002.

Institutional Review Board Statement: Not applicable.

Data Availability Statement: Informed consent was obtained from all subjects involved in the study.

Conflicts of Interest: The authors declare no conflict of interest.

\section{References}

1. Zou, C.; Dong, D.; Wang, Y.; Li, X.; Huang, J.; Wang, S.; Guan, Q.; Zhang, C.; Wang, H.; Liu, H.; et al. Shale gas in China: Characteristics, challenges and prospects (I). Pet. Explor. Dev. 2016, 42, 689-701. (In Chinese) [CrossRef]

2. Curtis, M.E.; Cardott, B.J.; Sondergeld, C.H.; Rai, C.S. Development of organic porosity in the Woodford Shale with increasing thermal maturity. Int. J. Coal Geol. 2012, 103, 26-31. [CrossRef]

3. Curtis, M.E.; Sondergeld, C.H.; Ambrose, R.J.; Rai, C.S. Microstructural investigation of gas shales in two and three dimensions using nanometer-scale resolution imaging. AAPG Bull. 2012, 96, 665-677. [CrossRef]

4. Chalmers, G.R.; Bustin, R.M.; Power, I.M. Characterization of gas shale pore systems by porosimetry, pycnometry, surface area, and field emission scanning electron microscopy/transmission electron microscopy image analyses: Examples from the Barnett, Woodford, Haynesville, Marcellus, and Doig units. AAPG Bull. 2012, 96, 1099-1119.

5. Guo, X.; Li, Y.; Liu, R.; Wang, Q. Characteristics and controlling factors of micropore structures of the Longmaxi shale in the jiaoshiba area, sichuan basin. Nat. Gas. Ind. 2014, 1, 165-171. [CrossRef]

6. Chalmers, G.R.; Ross, D.J.; Bustin, R.M. Geological controls on matrix permeability of Devonian Gas Shales in the Horn River and Liard basins, northeastern British Columbia, Canada. Int. J. Coal Geol. 2012, 103, 120-131. [CrossRef]

7. Chalmers, G.R.L.; Bustin, R.M. Geological evaluation of Halfway- DoigMontney hybrid gas shale-tight gas reservoir, northeastern British Columbia. Mar. Petrol. Geol. 2013, 38, 53-72. [CrossRef] 
8. Zhang, K.; Jia, C.; Song, Y.; Jiang, S.; Jiang, Z.; Wen, M.; Huang, Y.; Liu, X.; Jiang, T.; Peng, J.; et al. Analysis of Lower Cambrian shale gas composition, source and accumulation pattern in different tectonic backgrounds: A case study of Weiyuan Block in the Upper Yangtze region and Xiuwu Basin in the Lower Yangtze region. Fuel 2020, 263, 115978. [CrossRef]

9. Milliken, K.L.; Ko, L.T.; Pommer, M.; Marsaglia, K.M. SEM petrography of eastern Mediterranean sapropels: Analogue data for assessing organic matter in oil and gas shales. J. Sediment. Res. 2014, 84, 961-974. [CrossRef]

10. Loucks, R.G.; Reed, R.M.; Ruppel, S.C.; Hammes, U. Spectrum of pore types and networks in mudrocks and a descriptive classification for matrix-related mudrock pores. AAPG Bull. 2012, 96, 1071-1098. [CrossRef]

11. Klaver, J.; Desbois, G.; Urai, J.L.; Littke, R. BIB-SEM study of the pore space morphology in early mature Posidonia Shale from the Hils area, Germany. Int. J. Coal Geol. 2012, 103, 12-25. [CrossRef]

12. Loucks, R.G.; Reed, R.M.; Ruppel, S.C.; Jarvie, D.M. Morphology, genesis, and distribution of nanometer-scale pores in siliceous mudstones of the Mississippian Barnett Shale. J. Sediment. Res. 2009, 79, 848-861. [CrossRef]

13. Clarkson, C.R.; Solano, N.; Bustin, R.M.; Bustin, A.M.M.; Chalmers, G.R.L.; He, L.; Melnichenko, Y.B.; Radlinski, A.P.; Blach, T.P. Pore structure characterization of North American shale gas reservoirs using USANS/SANS, gas adsorption, and mercury intrusion. Fuel 2013, 103, 606-616. [CrossRef]

14. Yang, F.; Ning, Z.; Wang, Q.; Liu, H. Pore structure of Cambrian shales from the Sichuan Basin in China and implications to gas storage. Mar. Petrol. Geol. 2016, 70, 14-26. [CrossRef]

15. Ross, D.J.; Bustin, R.M. The importance of shale composition and pore structure upon gas storage potential of shale gas reservoirs. Mar. Pet. Geol. 2009, 26, 916-927. [CrossRef]

16. Tian, H.; Pan, L.; Xiao, X.; Wilkins, R.W.; Meng, Z.; Huang, B. A preliminary study on the pore characterization of Lower Silurian black shales in the Chuandong Thrust Fold Belt, southwestern China using low pressure $\mathrm{N}_{2}$ adsorption and FE-SEM methods. Mar. Pet. Geol. 2013, 48, 8-19. [CrossRef]

17. Li, X.; Jiang, Z.; Song, Y.; Zhai, G.; Bao, S.; Li, Z.; Tang, X.; Wang, P.; Li, T.; Wang, G.; et al. Porosity evolution mechanisms of marine shales at over-maturity stage: Insight from comparable analysis between Lower Cambrian and Lower Silurian inside and at the margin of Sichuan Basin, South China. Interpretation 2018, 6, 1-56. [CrossRef]

18. Chen, J.; Xiao, X. Evolution of nanoporosity in organic-rich shales during thermal maturation. Fuel 2014, 129, 173-181. [CrossRef]

19. Dong, T.; Harris, N.B.; Ayranci, K.; Twemlow, C.E.; Nassichuk, B.R. The impact of composition on pore throat size and permeability in high maturity shales: Middle and Upper Devonian Horn River Group, northeastern British Columbia, Canada. Mar. Pet. Geol. 2017, 81, 220-236. [CrossRef]

20. Zheng, H.; Gao, B.; Peng, Y.; Nie, H.; Yang, F. Sedimentary evolution and shale gas exploration direction of the Lower Silurian in Middle-Upper Yangtze area. J. Palaeogeogr. 2013, 15, 645-656. (In Chinese)

21. Zhou, W.; Xu, H.; Yu, Q.; Xie, R.; Deng, K. Shale gas-bearing property differences and their genesis between Wufeng-Lower Silurian shale and Qiongzhusi Formation in Sichuan Basin and surrounding areas. Lithol. Reserv. 2016, 28, 18-25. (In Chinese)

22. Zhao, W.; Li, J.; Yang, T.; Wang, S.; Huang, J. Geological difference and its significance of marine shale gases in South China. Pet. Explor. Dev. 2016, 43, 547-559. [CrossRef]

23. Wang, P.; Jiang, Z.; Ji, W.; Zhang, C.; Yuan, Y.; Chen, L.; Yin, L. Heterogeneity of intergranular, intraparticle and organic pores in Longmaxi shale in Sichuan Basin, South China: Evidence from SEM digital images and fractal and multifractal geometries. Mar. Pet. Geol. 2016, 72, 122-138. [CrossRef]

24. Wang, P.; Jiang, Z.; Chen, L.; Yin, L.; Li, Z.; Zhang, C.; Wang, G. Pore structure characterization for the Longmaxi and Niutitang shales in the Upper Yangtze Platform, South China: Evidence from focused ion beam-He ion microscopy, nano-computerized tomography and gas adsorption analysis. Mar. Petrol. Geol. 2016, 77, 1323-1337. [CrossRef]

25. Li, X.; Jiang, Z.; Wang, P.; Song, Y.; Li, Z.; Tang, X.; Li, T.; Zhai, G.; Bao, S.; Xu, C.; et al. Porosity-preserving mechanisms of marine shale in Lower Cambrian of Sichuan Basin, South China. J. Nat. Gas. Sci. Eng. 2018, 55, 191-205. [CrossRef]

26. Zhu, Y.; Hao, F.; Zou, H.; Cai, X.; Luo, Y. Jurassic oils in the central Sichuan basin, southwest China: Unusual biomarker distribution and possible origin. Org. Geochem. 2007, 38, 1884-1896. [CrossRef]

27. Li, P.P.; Hao, F.; Guo, X.S.; Zou, H.Y.; Yu, X.Y.; Wang, G.W. Processes involved in the origin and accumulation of hydrocarbon gases in the Yuanba gas field, Sichuan Basin, southwest China. Mar. Pet. Geol. 2015, 59, 150-165. [CrossRef]

28. Wei, G.; Xie, Z.; Song, J.; Yang, W.; Wang, Z.; Li, J.; Xie, W. Features and origin of natural gas in the Sinian-Cambrian of central Sichuan paleo-uplift, Sichuan Basin, SW China. Pet. Explor. Dev. 2015, 42, 768-777. [CrossRef]

29. Ma, Y.; Zhong, N.; Li, D.; Pan, Z.; Cheng, L.; Liu, K. Organic matter/clay mineral intergranular pores in the Lower Cambrian Lujiaping Shale in the north-eastern part of the upper Yangtze area, China: A possible microscopic mechanism for gas preservation. Int. J. Coal Geol. 2015, 137, 38-54. [CrossRef]

30. Jacob, H. Disperse solid bitumen as an indicator for migration and maturity in prospecting for oil and gas. Erdol Kohle 1985, 38, 365-374.

31. Scherdel, C.; Reichenauer, G.; Wiener, M. Relationship between pore volumes and surface areas derived from the evaluation of $\mathrm{N}_{2}$-sorption data by DR-, BET- and t-plot. Microporous Mesoporous Mater. 2010, 132, 572-575. [CrossRef]

32. Eliyahu, M.; Emmanuel, S.; Day-Stirrat, R.J.; Macaulay, C.I. Mechanical properties of organic matter in shales mapped at the nanometer scale. Mar. Pet. Geol. 2015, 59, 294-304. [CrossRef]

33. Van Sickel, W.A.; Kominz, M.A.; Miller, K.G.; Browning, J.V. Late Cretaceous and Cenozoic sea level estimates: Backstripping analysis of borehole data, onshore New Jersey. Basin Res. 2004, 16, 451-465. [CrossRef] 
34. Aplin, A.C.; Macquaker, J.H.S. Mudstone diversity: Origin and implications for source, seal, and reservoir properties in Pet. systems. AAPG Bull. 2011, 95, 2031-2059. [CrossRef]

35. Dong, D.; Cheng, K.; Wang, Y.; Li, X.J.; Wang, S.; Huang, J.L. Forming conditions and characteristics of shale gas in the Lower Paleozoic of the Upper Yangtze region, China. Oil Gas Geol. 2010, 31, 288-299. (In Chinese)

36. Zeng, J.; Jia, W.; Peng, P.; Guan, C.; Zhou, C.; Yuan, X.; Yu, C. Composition and pore characteristics of black shales from the Ediacaran Lantian Formation in the Yangtze Block, South China. Mar. Pet. Geol. 2016, 76, 246-261. [CrossRef]

37. Loucks, R.G.; Reed, R.M. Scanning-electron-microscope petrographic evidence for distinguishing organic-matter pores associated with depositional organic matter versus migrated organic matter in mudrock. GCAGS J. 2014, 3, 51-60.

38. Potter, P.E.; Maynard, J.B.; Depetris, P.J. Mud E Mudstones; Springer: Berlin/Heidelberg, Germany, 2005.

39. Huang, Z.L.; Guo, X.B.; Liu, B.; Zhang, D.S.; Zhang, J.B.; Qi, Y.A.; Wang, R. The reservoir space characteristics and origins of Lucaogou formation source rock oil in the Malang Sag. Acta Sedimentol. Sin. 2012, 30, 1115-1122.

40. Slatt, R.M.; O'Brien, N.R. Pore types in the barnett and woodford gas shales: Contribution to understanding gas storage and migration pathways in fine-grained rocks. AAPG Bull. 2011, 95, 2017-2030. [CrossRef]

41. Passey, Q.R.; Bohacs, K.M.; Esch, W.L.; Klimentidis, R.; Sinha, S. From oil-prone source rock to gas-producing shale reservoirgeologic and petrophysical characterization of unconventional shale-gas reservoirs. In Proceedings of the CPS/SPE International Oil \& Gas Conference and Exhibition, Beijing, China, 8-10 June 2010. SPE Paper 131350.

42. Mastalerz, M.; Schimmelmann, A.; Drobniak, A.; Chen, Y. Porosity of Devonian and Mississippian New Albany Shale across a maturation gradient: Insights from organic petrology, gas adsorption, and mercury intrusion. AAPG Bull. 2013, 97, 1621-1643. [CrossRef]

43. Ji, W.; Song, Y.; Rui, Z.; Meng, M.; Huang, H. Pore characterization of isolated organic matter from high matured gas shale reservoir. Int. J. Coal Geol. 2017, 174, 31-40. [CrossRef]

44. Hao, F.; Zou, H. Cause of shale gas geochemical anomalies and mechanisms for gas enrichment and depletion in high-maturity shales. Mar. Petrol. Geol. 2013, 44, 1-12. [CrossRef] 